\title{
A STUDY OF LIFE SKILLS IN RELATION TO ACADEMIC ANXIETY OF THE B. ED STUDENTS
}

\section{Dr. Alaka Das}

Associate professor. Dept. of Education KBVSASUN

The present study aims to assess the level of life skills of the B. Ed students as per their sex, academic background and academic qualification and relationship of life skills with academic anxiety. The findings of the study reveals that there exists no significant difference in life skills between male and female, graduate and postgraduate, teacher trainees coming from arts and science background. The findings of the study reveal that there exists significant negative relationship between life skills and academic anxiety of the B. Ed students.

\section{Life Skills -}

There is diverse understanding of life skills with no universally established classification. Life skills are defined as those abilities, attitudes, knowledge and behaviours that help in promoting mental well-being and competence to live with and relate to others. UNICEF defines life skills as a 'behaviour change or development approach designed to address a balance of three areas - knowledge, attitude and skills". Life Skills are the abilities for adaptive behaviour that enables an individual to deal effectively with the demands and challenges of everyday life (WHO).Though there are many life skills, in this study, life skills mean the ten core life skills as suggested by WHO, i.e. Self-awareness, Empathy, Interpersonal Relationship, communication, Critical Thinking, Creative thinking, Decision making, Problem solving, Coping with Stress, Coping with emotions.

\section{Academic Anxiety -}

Academic anxiety is a kind of state anxiety which relate to the impending danger from the environment of the academic institutions including teachers, subjects, etc. Prevailing education system has fuelled severe anxiety among the students that affect their performance. The B. Ed students are also not exception from this. In most Indian families, much emphasis is given on academic performance, but not in academic anxiety, which needs to be reduced for better academic growth. In this study, therefore an attempt is made to know the level of academic anxiety of the teacher trainees and also its relationship with their life skills.

\section{B. ED Programme -}

Teacher education programmes are the programmes for preparation of teachers. Although there have been educational initiatives to either introduce or incorporate life skills education with main stream curriculum, it still has not got its place into the mainframe of academics on a regular level. Somehow, the gap between knowledge aimed through the pure academics and preparing competent individuals who would be ready to take challenge in future world needs to be filled up through appropriate training of life skills.

\section{Significance of the study-}

In this age of information explosion, education system faces the ever increasing challenge of providing skills to acquire and process information. Lie skills as a teaching-learning approach is specifically designed to enhance efforts to positively develop or change behaviour, especially related to well being and healthy functioning in society. Since fewer studies are available in this area, an attempt has been made to study the level of life skills of the B. Ed students as per their sex, academic background and academic qualification and relationship of life skills with academic anxiety of the B.Ed Students.
"A Study of Life Skills in Relation to Academic Anxiety of the B. Ed Students"

\section{Objectives of the Study-}

1. To examine the level of life skills of the B. Ed students along with the significance of difference in the level of life skills as per their sex, academic qualification and status of service.

2. To examine the relationship between life skills and academic anxiety of the B. Ed students.

\section{Hypotheses of the Study-}

- There exists no significant difference in the level of life skills between male and female, graduate and postgraduate, science and arts background B. Ed students.

- There exists no significant relationship between life skills and academic anxiety of the B.Ed Students.

\section{Variables of the Study -}

Dependant variable-Life Skills.

Independent variable - Academic Anxiety

Background variables - Gender, Academic Qualification and Academic Background of the B.Ed Students.

\section{Review of Related Literature -}

Importance of life skills and it's intervention programme remains a significant area of interest to the researchers, practitioners. Smith \& et al., (2004) noted significant improvement in interpersonal relationship and reduction in aggression and behavioral problems. Vranda and Rao (2011) proved that life skills training enhanced their psychosocial Competencies. Dark (1988) found that highly anxious people have less available working memory capacity for task solution than their low anxious counterparts. In a study conducted by U. S. department of Education, strong negative relationship between academic anxiety and test performance have been reported. In another study, Garg G (2011) observed significant negative relationship between life skills and academic achievement of secondary school students. From the brief review made, it has been observed that though studies have been conducted on life skills, most of the studies focused on intervention programme. It is felt that, there are still gap remains in studying academic anxiety in relation to life skills. Therefore, in this paper, a humble effort has been made to study the relationship between life skills and academic anxiety of B. Ed Students.

\section{Methodology of the Study -}

Descriptive Survey method has been used in the study.

Sample - The Sample of the study consisted of 90 B. Ed students selected randomly from 3 teacher training colleges of rural Kamrup district of Assam. In terms of gender, it consisted of 30 male and 60 female teacher trainees.

Research Tools - The tools used for collection of data are- 
- Adapted version of 'Life Skills Scales for teacher Trainees" developed and standardized by Sarika Chauhan (2016). The scale consisted of 125 statements that cover all the ten core life skills suggested byWHO.

- Academic Anxiety Inventory developed by the investigator that consisted of total 50 items. The components of the inventory are - Worry, Emotionality, Task generated interference, Study skill deficit and procrastination.

- Statistical Analysis- Mean, S. D. And t' test were used to assess the significant differences between male and female, graduate and postgraduate, science and arts background B. Ed students. Co-efficient of co-relationship technique was used to know the relationship between life skills and academic anxiety.

Delimitation of the Study - The findings of the study will be limited to the selected teacher training colleges and samples only, as the sample size is small.

\section{Analysis and Discussion of the Study-}

Table 1: Level of Life Skills and Academic Anxiety of the B. Ed students, $\mathbf{N}=90$

Table 2 Significance of differences between male and female, graduate and post graduate, Academic Background of B. Ed Students, $\mathbf{N}=\mathbf{9 0}$

\begin{tabular}{|c|c|c|c|c|c|c|c|}
\hline Dimensions & Variables & & $\mathrm{N}$ & Mean & S.D & $\mathrm{t}^{\prime}$ & Level of significance \\
\hline \multirow[t]{6}{*}{ Life Skills } & \multirow[t]{2}{*}{ Sex } & Male & 30 & 340.73 & 14.26 & \multirow[t]{2}{*}{.67} & \multirow[t]{2}{*}{ Not significant } \\
\hline & & Female & 60 & 342.71 & 10.89 & & \\
\hline & \multirow[t]{2}{*}{ Academic Qualification } & Graduate & 44 & 343.72 & 10.31 & \multirow[t]{2}{*}{1.078} & \multirow[t]{2}{*}{ Not significant } \\
\hline & & Post Graduate & 46 & 341.08 & 12.99 & & \\
\hline & \multirow[t]{2}{*}{ Academic Background } & Science & 36 & 343.72 & 11.77 & \multirow[t]{2}{*}{1.09} & \multirow[t]{2}{*}{ Not Significant } \\
\hline & & Arts & 54 & 340.92 & 12.23 & & \\
\hline
\end{tabular}

From the table 2, the $t$, value of mean life skill score of male and female B. Ed students was found to be .67 which is not found to be statistically significant. Therefore, the null hypothesis of nonexistence of significant difference in the mean values of male and female B. Ed students is accepted. The findings of the study support the observation made by Garg G. (2011). It is also evident that though the concerned $t^{\prime}$ value of mean life score of graduate and post graduate (1.078) is not found to be statistically significant, graduate B. Ed students have higher mean life skill score than the post graduate students.

Regarding the mean score difference of life skills scores of B. Ed students from Science and Arts background B. Ed students, the calculated $t$ ' value of 1.09 is not found significant at any level of significance. Therefore, the hypothesis of no significant difference in mean life skills scores of graduate and post graduate level is accepted. The findings regarding non-significant difference in life skills among the B. Ed students as per background variables, indicates that, due to maturity level, experience and similar learning environ may have impact on the level of life skills of the B.Ed students.

Table 3: Significance of Relationship between Life skills and Academic Anxiety of B.Ed Students.

\begin{tabular}{|l|c|l|}
\hline Variables & $\mathrm{r}$ & Level of Significance \\
\hline Life Skills & -.305 & $\begin{array}{l}* * \\
\text { Significant at .001 level }\end{array}$ \\
\hline Academic Anxiety & & \\
\hline
\end{tabular}

From the table 3, As the calculated $r^{\prime}$ value (-.305) is higher than the table value at .01 level of significance, therefore, null hypothesis of no significant relationship between life skills and academic anxiety score is rejected. Similar observation of negative relationship between life skills and academic anxiety score was reported by Garg, G (2011).

\section{Major Findings of the Study -}

- The level of Life Skills and Academic Anxiety of the B. Ed Students are of average level.

- There exist no significant difference in Life Skills of male and female, graduate and post graduate, Science and Arts

\begin{tabular}{|l|l|l|l|l|l|}
\hline Sl. N & Variables & N & M & Mdn & S. D \\
\hline 1 & Life Skills & 90 & 342.05 & 347.2 & 11.99 \\
\hline 2 & Academic Anxiety & 90 & 95.64 & 97.81 & 12.71 \\
\hline
\end{tabular}

From the table 1, it has been observed that the mean life skills score of the sample group is 342.05 with standard deviation of 11.99, which indicates average level of life skills of the B. Ed students. Similarly, the mean score of academic achievement 95.64 with standard deviation of 12.71 indicates average level of academic anxiety of the B. Ed students. The reasons for average level of life skills among the $B$. Ed students may be because of limited scope of learning about life skills in curricular aspect and non-incorporation of proper emphasis in this respect. Besides, average level of academic anxiety may also reflect limited coping skill with regular academic activities.

Objective 2- Difference in mean scores of life skills and academic anxiety of the B. Ed students as per their Gender, Academic Qualification and Academic Background.

Background B.Ed students.

- There exists significant negative relationship between life Skills and Academic Anxiety of B.Ed students.

\section{Educational Implication and Suggestion -}

- To improve the level of life skills of the B. Ed students, proper curricular orientation along with intervention programme should be included at teacher training level.

- Different classroom activities like classroom discussion, brainstorming session, role playing, group discussions, games and simulations, analysis of situations and case studies, debates need to be included in teaching methods.

- To minimize test anxiety and enhance academic performance, students may incorporate and inculcate different relaxation techniques, adopt self-talk, teachers may help in managing anxiety by discussing with students, parents and peers.

\section{CONCLUSION-}

This study may develop an insight to concerned stake holders to find the reasons and remedies of anxiety in students and provide the ways to develop essential skills and abilities among adolescents and youth. It is expected that the future teachers would develop essential constructs of life skills which not only help them to face challenges in life confidently but also to enable them to train their students, to utilize the skills in their personal and professional life.

\section{REFERENCES -}

1. Chauhan, S (2016) "Development and Try out of a Programme on Life Skills for Pre Service TeacherTrainees"Ph. D thesis.

2. Geeta, G. "Life Skills and Academic Anxiety of Secondary School School Children" Edutracks Sept 201 1,Voll-1 1,N0. 1 (23-270

3. Lakshmi GB.' Life skill education". University News 2009;47(8):14-17.

4. Mishra, K,D. (2015) "Academic Anxiety Scale"

6. UNESCO (2001).Life Skills in Non-Formal Education:A review, UNESCO 